\title{
As mortes de Matheusa em uma notícia do Estadão: estudos interseccionais sobre preconceito, discriminação e violência física em relação à diversidade de gêneros
}

The Deaths of Matheusa in the Estadão Newspaper: Intersectional Studies on Prejudice, Discrimination and Physical Violence Regarding Gender Diversity

Daniel de Mello Ferraz*

*Universidade de São Paulo (USP), São Paulo, São Paulo / Brasil danielfe@usp.br

https://orcid.org/0000-0002-8483-2423

Micheline Mattedi Tomazi**

**Universidade Federal do Espírito Santo (UFES), Vitória, Espírito Santo / Brasil michelinetomazi@gmail.com

https://orcid.org/0000-0002-2246-7061

Ariel Sessa***

***Universidade Federal do Espírito Santo (UFES), Vitória, Espírito Santo / Brasil arielsessa@gmail.com

https://orcid.org/0000-0001-7589-6436

RESUMO: Neste artigo problematizamos as mortes física e simbólicas, de Matheusa, mulher/homem trans não binária, anunciadas em uma notícia do jornal O Estado de São Paulo, em 2018. O aparato teórico é multidisciplinar e, portanto, enseja o diálogo entre a sociologia, a análise crítica do discurso (ACD) e a linguística aplicada (LA). A metodologia é qualitativa e os métodos de investigação advêm dos procedimentos interpretativos dos estudos sociológicos interseccionais e das ferramentas da ACD. O artigo está dividido em cinco partes. Após a introdução, a segunda parte investiga a interseccionalidade nos estudos de gênero e de raça. Na terceira, problematizam-se os gêneros e as (homos)sexualidades. Raça, racismo são os temas da quarta seção. Finalmente, discurso, mídia e ideologia mostram como as demais mortes de Matheusa são explicitadas discursivamente. 
PALAVRAS-CHAVE: interseccionalidade; gênero; raça; (homos)sexualidade; ACD; mídia.

\begin{abstract}
This article discusses the physical and symbolic deaths of Matheusa, a trans non-binary person, announced in a news article of $O$ Estado de São Paulo in 2018. The theoretical background used is multidisciplinary, thus enabling the dialogue between sociology, Critical Discourse Analysis (CDA) and AL. This a qualitative study, and the investigation methods come from the interpretive procedures of intersectional sociological studies and the instruments of CDA. The article is thus divided into five parts. After the introduction, the second part investigates intersectionality in gender/race studies. The third section investigates gender and homosexuality. Race and racism are the themes of the fourth section. Finally, discourse, media and ideology showcase how the other the deaths of Matheusa are presented discursively.
\end{abstract}

KEYWORDS: intersectionality; gender; race; homosexuality; CDA; media.

\title{
1 Considerações iniciais: a primeira morte de Matheusa
}

O Brasil, segundo dados apresentados no relatório da Associação da Parada do Orgulho LGBT de São Paulo, lidera o ranking de assassinatos de transexuais, pessoas que se identificam com um gênero diferente do que lhes foi atribuído ao nascer, registrando 167 mortes entre $1^{\circ}$ de outubro de 2017 e 30 de outubro de 2018 (VIANA, 2019). Esses dados demonstram a vulnerabilidade desse grupo, bem como o processo de exclusão, discriminação e violência pelo qual tem sido marcado ao longo dos anos. As estatísticas revelam, também, que muitas vítimas transexuais assassinadas sequer chegam a ter sua morte registrada, e estima-se que o número seja bem maior que o apresentado nos dados oficiais. Muitos casos não são devidamente registrados e não podem ser considerados pertencentes à categoria de assassinatos de pessoas transexuais, o que mascara a opressão a esse tipo de violência por parte da sociedade.

Entretanto alguns casos emblemáticos de violência contra pessoas desse e de outros grupos minoritários ganham as páginas da grande mídia ou são escolhidos por ela para participar do pacote mercadológico a ser oferecido para compra pela "sociedade do espetáculo", para usar o termo de Debord (1997). Segundo Freitas (2018), entre outros, os crimes dolosos contra a vida têm conquistado lugar de destaque na mídia que, longe de narrar as condições de possibilidade de um acontecimento, passou a publicizá-los, tornando-se uma agência de investigação, atuando como instância do julgamento público e aplicando sanções morais, além de emitir seu ponto de vista e tomar posições sem, contudo, mostrar "a cara da 
violência" (FREITAS, 2018, p. 183). Ao dar amplitude a determinados casos, a mídia implanta na opinião pública a versão que, "sob sua ótica e de acordo com seus critérios editoriais, seria a mais consentânea com a realidade" e extrapola seu direito constitucional de transmitir uma informação para investir em fatos e versões muitas vezes "distorcidas, estereotipadas e hegemônicas" (FREITAS, 2018, p. 293).

O aparato teórico que norteia este artigo é multidisciplinar e, portanto, permite o diálogo entre diferentes disciplinas como a sociologia, a análise crítica do discurso e a linguística aplicada. Dialogamos com autores dessas diferentes disciplinas e campos teóricos porque acreditamos que o tema deste artigo não merece um olhar que privilegie alguma área específica, mas sim um olhar inquietante, perscrutador, militante e resistente, que só pode ser encontrado no entrecruzamento teórico, nos diferentes olhares, na diversidade, em tudo que permite ao pesquisador um olhar mais aprofundado para as questões sociais, que são também linguísticas, históricas, sociológicas, antropológicas etc.

Nessa problemática, que envolve mídia, sociologia do direito, análise crítica do discurso e linguística aplicada, escolhemos o caso do assassinato de Matheusa, negra, mulher, homem, não binária, ativista, artista, não hegemônica, não convencional. Sua morte física foi declarada pela mídia de forma ampla, sensacionalista, espetaculosa e, não raro, para casos que envolvem minorias, tendenciosa, fomentando estereótipos sociais de gênero, raça, condição socioeconômica e cultural. O objetivo deste artigo é analisar como Matheusa e "suas mortes" foram apresentadas no discurso de uma notícia divulgada pelo jornal O Estado de São Paulo (PENNAFORTE, 2018).

A metodologia que embasa esta reflexão analítica é qualitativa/ interpretativista e os métodos de investigação advêm dos procedimentos interpretativos dos estudos sociológicos interseccionais e das ferramentas analíticas da Abordagem Sociocognitiva Crítica do Discurso (ACD), ${ }^{1}$ por

\footnotetext{
1 Tendo em vista os diferentes tipos de análise crítica do discurso que podem ser teoricamente e analiticamente diversificados, optamos pela proposta sociocognitiva do discurso por entendermos que ela apresenta um quadro conceitual que permite dialogar com os estudos sociológicos interseccionais por considerar que, para compreender a relação entre o discurso e a sociedade, é possível levar em conta as interfaces cognitivas (pessoal e social) para explicar como as categorias sociais e culturais se entrelaçam na diversidade das interseccionalidades. Assim, a sigla ACD neste texto se refere a esta abordagem.
} 
meio da análise documental e da interpretação de uma notícia publicada no jornal O Estado de São Paulo, no dia 6 de maio de 2018. Como metodologia, a interseccionalidade facilita e promove "diferentes interpretações dos mesmos fatos", incorporando e especificando "a sobreposição de múltiplas dinâmicas sociais" (CLARKE; MCCALL, 2013, p. 351).

Desse modo, este artigo está dividido em cinco partes. Após esta introdução a segunda parte investiga a interseccionalidade e as discriminações de gênero e de raça, buscando conectá-las com as identidades de Matheusa. Na terceira seção, problematiza-se especificamente os gêneros e as (homos)sexualidades entrecruzadas com nossa percepção da segunda morte, simbólica, de Matheusa. Raça, racismo e interseccionalidade e a terceira morte de Matheusa são os temas da quarta seção. Finalmente, discurso, notícia e ideologia na ACD apresentam como as demais mortes de Matheusa são explicitadas discursivamente. Nas considerações finais, a interseccionalidade no caso Matheusa é colocada como estudo de grande potencialidade para a linguística aplicada, os estudos midiáticos/culturais e a educação linguística.

\section{Interseccionalidade e discriminações de gênero e de raça: as identidades de Matheusa}

Os estudos sobre a interseccionalidade (COOPER, 2015; CRENSHAW, 1989; LANEHART, 2009; MCCALL, 2005;), embora consagrados há três décadas, parecem estar em sua fase inicial no bojo da linguística aplicada. Para Cooper (2015), embora tenham adquirido status ubíquo entre os estudos feministas e em outros círculos acadêmicos, "dando a impressão que 'todos' realizam um trabalho interseccional, parece haver pouco consenso sobre o que a interseccionalidade realmente significa" (COOPER, 2015, p. 1, tradução nossa²).

Para a feminista, blogueira, doutora em estudos de gêneros e docente da University of Malay (Malásia) Alicia Izharuddin, interseccionalidade, "como o substantivo sugere, é o ponto de contato entre linhas, elementos, categorias. Como ferramenta analítica, focaliza os sujeitos que assumem as

\footnotetext{
${ }^{2}$ Todas as citações que foram publicadas originalmente em inglês serão traduzidas pelos autores deste artigo. Todas as traduções que constam neste artigo são de responsabilidade de seus autores.
} 
posições nessas interseções" (IZHARUDDIN, 2010, p. 2). Como vetores e nódulos que se conectam e desconectam, de forma rizomática e não hierarquizada, a interseccionalidade pode ser inicialmente entendida como "um processo do 'fazer"', um movimento, um verbo, um fazer in situ, onde "intersecções concretas, hierarquias e elaboração não são predeterminadas" (STAUNAES, 2003, p. 101). De acordo com Izharuddin (2010, p. 2), ela pode ser compreendida por prismas multifacetados: McCall (2005, p. 1771) aborda "as relações entre múltiplas dimensões e modalidades de relações sociais e formações de sujeito". A interseccionalidade também tem sido descrita como encruzilhada (CRENSHAW, 1991, p. 1245)", em que "as múltiplas noções de interseccionalidade refletem seu caráter amorfo e expansivo, mas ressaltando que todas as definições são a recuperação da mulher como sujeitos dos múltiplos emaranhados de sua contextualização social" (IZHARUDDIN, 2010, p. 2).

Uma breve genealogia do termo interseccionalidade retoma os questionamentos dos impactantes estudos feministas, preconizados por mulheres, em sua maioria brancas, de classe média e pertencentes à elite intelectual das décadas de 1970 e 1980. O termo, cunhado nas publicações e teorizações de Crenshaw (1989, 1991), surgiu como aparato teórico que buscou focalizar e valorizar os posicionamentos de mulheres negras nas leis e movimentos de direitos civis nos Estados Unidos, constituindo-se na "mais visível e duradoura contribuição que o feminismo, em particular, o feminismo negro, vem realizando nos últimos 25 anos em relação aos estudos da teoria social crítica" (COOPER, 2015, p. 1). Crenshaw (1989, p. 139), em seu artigo seminal "Demarginalizing the intersection of race and sex: a black feminist critique of antidiscrimination doctrine, feminist theory and antiracist politics", preconiza as problemáticas consequências da "tendência de considerar-se raça e gênero como categorias mutuamente unívocas da experiência". A autora condena essa tendência, mantida por uma single-axis framework, qual seja, uma estrutura social com um eixo único/unívoco que permeia as leis antidiscriminatórias e se refletem na teoria feminista e na política antirracista (CRENSHAW, 1989), apagando e silenciando as mulheres negras, suas identidades e subjetividades. Assim, a interseccionalidade deve, além de "abarcar e expandir um conjunto de problemas sociais que as pensadoras negras têm enfrentado por aproximadamente um século" (COOPER, 2015, p. 4), desafiar a simples ideia de somatória de racismo e sexismo, como se essa adição pudesse 
dar conta das condições subalternizadas às quais as mulheres negras são subordinadas.

As questões de interseccionalidade, política identitária e a violência em relação às mulheres negras são alargadas e intensificadas em "Mapping the margins: intersectionality, identity politics and violence against women of color" (CRENSHAW, 1991), pois, conforme apregoa a autora,

a inclusão da política de identidade, no entanto, encontra-se em tensão com as concepções dominantes de justiça social. Raça, gênero e outras categorias de identidade são tratados com maior frequência no discurso liberal dominante como vestígios de preconceito ou dominação - isto é, como estruturas intrinsecamente negativas nas quais o poder social trabalha para excluir ou marginalizar aqueles que são diferentes. (CRENSHAW, 1991, p. 1424)

Conforme Cooper (2015), essa segunda reflexão de Crenshaw foi similarmente profícua para os estudos sobre a interseccionalidade, visto que a feminista discorreu sobre as relações sociais macro versus micro por meio da teorização da interseccionalidade estrutural e da interseccionalidade política. A estrutural referia-se a "uma convergência de 'raça, gênero, e dominação de classe', na qual intervenções sociais projetadas para melhorar os resultados do racismo, ou sexismo, ou a pobreza seriam insuficientes para atender às necessidades de uma mulher de cor" (COPPER, 2015, p. 2), pois essa mulher de cor foi peremptoriamente marginalizada pela interação desses três sistemas de poder. Por exemplo, no "caso" Matheusa, a interseccionalidade estrutural critica as interdiscursividades naturalizadas e hegemônicas sobre raça, gênero (binário) e classe baseadas na heteronormatividade que, além de não atenderem às "necessidades de uma mulher de cor", silenciam e negam, como veremos, as suas identidades de trans, não binária, mulher, negra, pobre, entre tantas outras. Já a interseccionalidade política, por outro viés, tenciona "enfatizar que as mulheres negras estão imbricadas em pelo menos dois grupos subordinados que buscam agendas políticas conflitantes" (CRENSHAW, 1991, p. 1252). Ou seja, em Matheusa, percebem-se muitos grupos de subordinação e subalternidade: mulher/homem, trans, não binária, negra e de classe econômica desprivilegiada.

Aprofundando os conceitos em torno da interseccionalidade, McCall (2005) dimensiona três categorias fundamentais: 
1. A complexidade "intracategórica", em que "analisa-se um único grupo social, evento ou conceito - e busca-se conectá-lo com as demais categorias verificando as influências de gênero, raça, classe" (MCCALL, 2005, p. 1787). Matheusa, como veremos adiante, é definida pelo Estadão, ora nos ditames heteronormativos, como Matheus, estudante e homem, ora como Matheusa, pois "identificava-se tanto com o gênero masculino quanto com o feminino" (PENNAFORTE, 2018, p. 1). Diante do exposto, essa categoria nos remete às complexidades intrínsecas à categoria de gênero, dado que esta vai muito além da dicotomia homem versus mulher.

2. A complexidade intercategórica desvela que há relações desiguais entre os grupos sociais. "Essa abordagem concentra-se na complexidade de relacionamentos entre os vários grupos sociais por meio de categorias analíticas. O método é sistematicamente comparativo" (MCCALL, 2005, p. 1785). Exemplificando, novamente com Matheusa, o jornal prossegue a notícia afirmando que "existe a suspeita que o crime foi motivado por LGBTfobia” (PENNAFORTE, 2018, p. 1). Em contextos neoconservadores e homofóbicos, parece claro o posicionamento do jornal: embora o desejo de neutralidade esteja, sempre, presente, a categoria LGBT (ou LGBTQIA+), além de "valer menos", deve ser eliminada ou excluída, por fazer parte da categoria "anormal, abjeto, doença, disfunção, entre outras".

3. A complexidade "anticategórica" argumenta que as categorias sociais são uma construção arbitrária da história e da linguagem e que elas "contribuem pouco para entender as maneiras pelas quais as pessoas vivenciam a sociedade" (MCCALL, 2005, p. 1778). Essa abordagem, extremamente questionadora, tem sido eficaz ao desafiar a singularidade, separação e integridade de uma vasta gama de categorias sociais. Retomando o caso Matheusa, percebemos, na notícia em questão, a construção arbitrária e o apagamento de outras identidades da estudante quando o jornal, mormente a identifica com o gênero masculino. Por meio desta categoria podemos (e devemos) questionar e (re)visionar as identidades de gênero e a orientação sexual arbitrariamente apagadas: Matheusa é mulher? Trans? Queer? Gay? Bi? Não binária? Ser humano?

Por outros vieses, sobretudo identitários, Lanehart (2009, p. 2) atribui a proeminência e concretização dos estudos interseccionais à socióloga Patricia Hill Collins e à pesquisadora Susanne Knudsen, para quem a interseccionalidade é uma teoria que analisa como "as categorias sociais e 
culturais se entrelaçam. As relações entre gênero, raça, etnia, deficiência, sexualidade, classe e nacionalidade são examinadas em vários níveis com intuito de explicar as várias desigualdades que existem na sociedade" (KNUDSEN, 2006, p. 61). Conforme Knudsen (2006, p. 61), essas categorias não são independentes umas das outras, e, ainda resultam em "formas de opressão inter-relacionadas que se manifestam em múltiplas formas de discriminação". Assim, as categorias sociais são deslocadas de um "ser essencial para um devir, em construção" (IZHARUDDIN, 2010, p. 4). Elas são construídas, desconstruídas e reconstruídas de várias maneiras em relação a outras categorias, em redes de significação socialmente e contextualmente (re)construídas:

FIGURA 1 - Diversidade e interseccionalidade (LANEHART, 2009, p. 3), traduzida pelos autores.

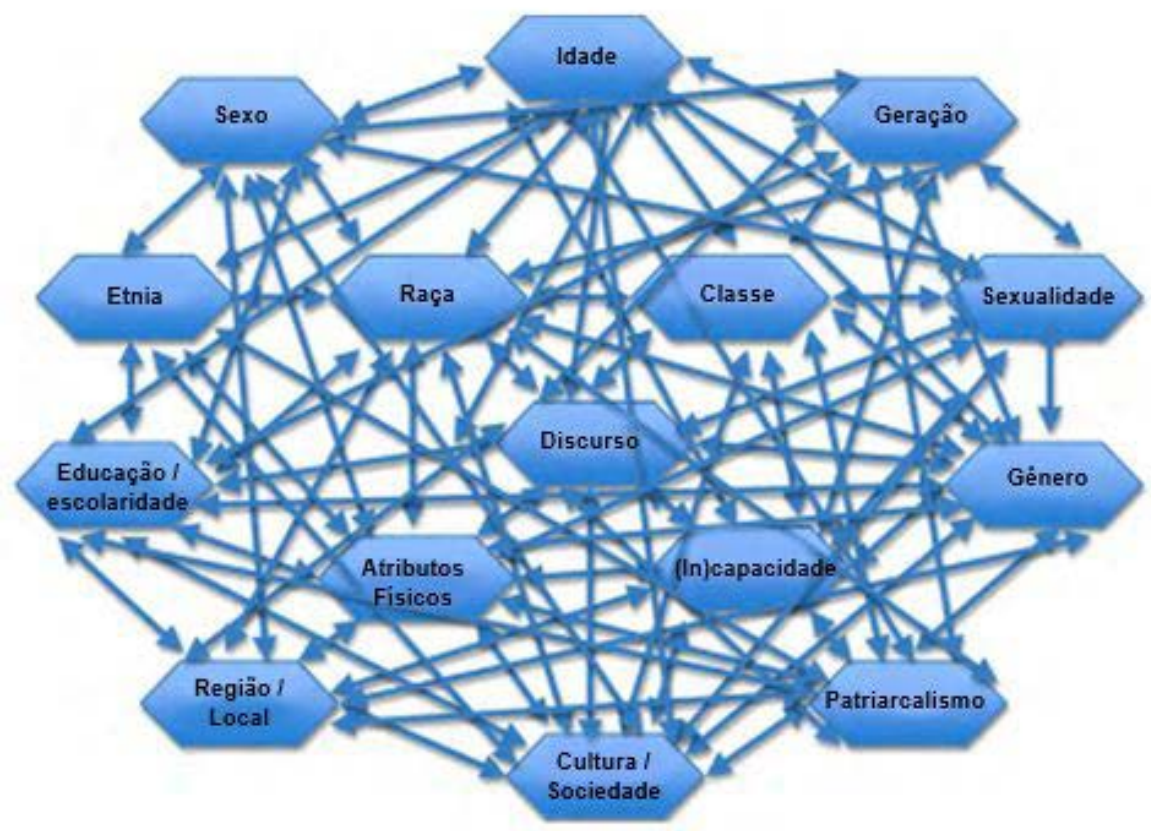

Destarte, "saber que as mulheres negras vivem em uma sociedade racista é insuficiente para descrever as suas experiências. É necessário conhecer como se constituem a sua etnia, gênero, geração, classe, orientação sexual, etc." e, ainda, "é preciso examinar constantemente as formas como 
as instituições e estruturas hegemônicas moldam e são moldadas por questões de gênero, raça, etnia, religião, sexualidade, classe, nacionalidade, etc.” (LANEHART, 2010, p. 3). Trata-se, por conseguinte, de vislumbrar uma interseccionalidade ensejada na perspectiva feminista pós-estruturalista de identidades, indagando, por exemplo, “onde fica a mulher na análise interseccional?".

Não obstante, algumas discussões autocríticas em torno da interseccionalidade são realizadas por Cooper (2015, p. 2), pois, nas palavras da autora, muitos teóricos estão desapontados com a incapacidade da interseccionalidade em "dar conta de todas as existências de identidade, diante de múltiplas categorias identitárias, como sexualidade, nação, religião, idade e capacidade, nos discursos interseccionais contemporâneos". Nos entendimentos de Bilge (2013, apud COOPER, 2015, p. 2) assim "como outras teorias em movimento (traveling theories) que circulam por meio das disciplinas e geografias, a interseccionalidade tem sido vítima de distorções generalizadas, deslocamento e desarticulação”. Kwan (2000, p. 687), na mesma direção, admoesta que, embora a interseccionalidade "ilumine os caminhos pelos quais as vítimas da opressão necessitam reconhecimento em seus próprios termos, ela nos diz muito pouco sobre as condições emocionais e psicológicas, e a subjetividade das pessoas enclausuradas nas trajetórias das categorias que se cruzam".

Como vimos, as identidades humanas são complexas e as identidades de cada ser humano são ainda mais complexas. Nesse sentido, elas, as identidades talvez sejam o que nos conduz às identidades de Matheusa multifacetadas e desafiadoras dos padrões heteronormativos.

\section{Gêneros e (homos)sexualidades: a segunda morte de Matheusa}

Nesta seção discutiremos brevemente os conceitos de gêneros e (homos)sexualidades e exploramos as suas potencialidades (e fraquezas) quando tecidos na interseccionalidade/ assemblage. Busca-se, ainda, entrecruzar os estudos interseccionais com os de gênero e (homos)sexualidades demonstrando-se como se deu, via discurso jornalístico, a segunda morte (simbólica) de Matheusa, qual seja, a morte da sua(s) identidade(s) de gênero. Para isso, retomamos as três categorias da interseccionalidade proposta por McCall (2005) na seção 2, e as relacionamos com os estudos interseccionais de gênero e sexualidades de Monro e Richardson (2010). Apresentamos, 
além disso, o conceito de assemblage que, assim como a interseccionalidade, provê solo fértil para as discussões aqui apresentadas.

Em breves palavras, as identidades são "constituídas no contexto da cultura, produzem-se em meio a disputas, supõem classificações, ordenamentos, hierarquias; elas estão sempre implicadas num processo de diferenciação" (LOURO, 2000, p. 63). Para Hall (2006, p. 9), por conta das transformações na sociedade (pós)moderna a partir do final do Século XX, "as paisagens culturais de classe, gênero, sexualidade, etnia, raça e nacionalidade", que no passado se viam como sólidas, estão sendo fragmentadas. No tocante às identidades, Hall assevera que ao sujeito pósmoderno não cabe mais uma "identidade fixa, essencial ou permanente. A identidade torna-se uma 'celebração móvel: formada e transformada continuamente em relação às formas pelas quais somos representados ou interpelados pelos sistemas culturais que nos rodeiam" (HALL, 1992, p. 12).

Já em relação aos gêneros e sexualidades, Louro $(2008$, p. 18) assegura que "a construção dos gêneros e das sexualidades se dá através de inúmeras aprendizagens e práticas, insinua-se nas mais distintas situações, é empreendida de modo explícito ou dissimulado por um conjunto inesgotável de instâncias sociais e culturais". Ou seja, trata-se de um processo "minucioso, sutil, sempre inacabado" em que instituições ou formações discursivas como família, escola, religião, direito, medicina "mantêm-se, por certo, como instâncias importantes nesse processo constitutivo" (LOURO, 2008, p. 18). Posto que "as identidades de gênero remetem-nos às várias formas de viver a masculinidade ou a feminilidade" e "o conceito de sexualidade é utilizado para se referir às formas como os sujeitos vivem seus prazeres e desejos sexuais [...] relacionadas aos diversos arranjos e parcerias que os sujeitos inventam e põem em prática para realizar seus jogos sexuais" (LOURO 2000, p. 63-64), pode-se reiterar que o complexo contínuo entre gênero e sexualidade se baseia em construtos sociais, culturais e históricos. Resumidamente, assim como o gênero está para a identidade (a maneira como o sujeito deseja ser visto na sociedade: homem, mulher, gay, lésbica, trans, entre outros), a sexualidade/orientação sexual está para a subjetividade (a maneira - pessoal ou pública - pela qual o sujeito realiza a sua sexualidade: heterossexual, homossexual, bissexual). Matheusa, por exemplo, declaravase pertencente ao gênero não binário (nem homem, nem mulher, nem gay, nem trans, porém entrecruzada em todos eles) e homossexual. 
Segundo Butler (2003, p. 28), gênero pode ser compreendido como "um significado que é assumido por um corpo diferenciado sexualmente"; um significado que só existe em relação ao outro corpo, como uma marca de diferença "biológica, linguística e/ ou cultural" (BUTLER, 2003, p. 28). É por essa razão que a autora e um conjunto de feministas que compartilha de suas ideias consideram gênero como algo que não pode ser fixo ou fixado, imutável. Pelo contrário, gênero é concebido como um conjunto de relações complexas e imbricadas no tecido social. Entretanto, Butler expõe, reiterando Beauvoir, que somente "o gênero feminino é marcado, pois a pessoa universal e o gênero masculino se fundem em um só gênero, definindo com isso, as mulheres nos termos do sexo deles e enaltecendo os homens como portadores de uma pessoalidade universal que transcende o corpo" (BUTLER, 2003, p. 28). Para a autora, os "gêneros 'inteligíveis' são aqueles que, em certo sentido, instituem e mantêm relações de coerência e continuidade entre sexo, gênero, prática sexual e desejo" (BUTLER, 2003, p. 28). Igualmente, imbricados em tais continuidades e coerências, estão aqueles cujo sexo, gênero, prática sexual e desejo diferem da normatividade/heteronormatividade/heterossexualidade, a saber, os LGBT (ou LGBTQIA+), que certamente compõem, para uma grande parcela da sociedade, os gêneros ininteligíveis, muitas vezes abjetos.

Vale relembrar que os estudos da interseccionalidade nasceram da "crítica aos modelos de desigualdade que moldaram as relações sociais, as quais foram operacionalizadas de forma aditiva e estratificada" (MONRO; RICHARDSON, 2010, p. 99). Ainda, "a interseccionalidade pode ser usada como 'um método para interrogar a reprodução institucional da desigualdade, seja no nível do estado, da família ou das estruturas legais em geral"' (MONRO; RICHARDSON, 2010, p. 99). Nesse sentido, operando tanto como crítica aos modelos de desigualdades quanto como método de interrogação da reprodução dessas desigualdades, a interseccionalidade não poderia se eximir dos debates sobre gêneros imbricados com as sexualidades. Entretanto, de acordo com os autores, percebe-se uma tendência de se omitir ou negligenciar os estudos sobre sexualidade dentro dos estudos interseccionais: "uma revisão de literatura demonstra que os estudos interseccionais focalizaram gênero, etnia e classe e tenderam a apagar as identidades de gênero não-binárias" (MONRO; RICHARDSON, 2010, p. 99). Complementam o debate Yenaki, Michaelis e Dietzi (2010) afiançando que "a relação entre a teoria queer e a interseccionalidade permanece 
complicada, apesar dos óbvios paralelos entre os dois movimentos críticos", porém "há uma negligência relativa da sexualidade nas teorias da interseccionalidade quando dos estudos de gênero e, em segundo, há um silêncio contínuo sobre a interseccionalidade em uma genealogia predominantemente branca da teoria queer" (YEKANI; MICHAELIS; DIETZI, 2010, p. 78).

Ainda assim, é perceptível a potencialidade desses estudos para o campo conflitante da(s) sexualidade(s). Uma dessas potências advém das releituras de Monro e Richardson (2010) sobre as três categorias da interseccionalidade de McCall (2005). Ressignificadas e aqui entrelaçadas, por exemplo, com as mortes de Matheusa, essas categorias nos ajudam a perceber as relações de poder internas, externas e as suas interrelações categóricas:

1. A interseccionalidade "intracategórica" de McCall pode ser redimensionada a fim de percebermos as diferenças internas nas comunidades LGBT, ou como muitos vêm defendendo, nas comunidades LGBTQIA+. A própria sigla, em constante expansão e movimento, revela que as trans, os/as bissexuais, os/as queer/ questionadores, as/os intersexuais, os/as assexuais e todos os/as demais (sinal de + ), embora tenham sido contemplados recentemente, ampliaram o escopo das identidades de gêneros e emaranharam "tensões, marginalizações e rasuras relativas a estes grupos, que contêm, eles próprios, consideráveis diversidades (incluindo as diversas opiniões sobre a sigla LGBT)" (MONRO; RICHARDSON, 2010, p. 214).

É desse modo que, quando Matheusa, como veremos na análise discursiva da seção 5, é retratada, mormente como pertencente ao sexo masculino e identidade de gênero hétero (por exemplo, "o estudante da Universidade Estadual do Rio de Janeiro (Uerj), Matheus Passarelli Simões Vieira, de 21 anos, desaparecido desde o dia 29 de abril, foi assassinado numa favela da zona Norte do Rio de Janeiro" (PENNAFORTE, 2018, p. 1), a sua primeira morte simbólica é atestada: extirpa-se a sua principal identidade de gênero, seu declarado não binarismo e a sua sexualidade.

2. A abordagem "intercategórica" é "claramente relevante para examinarmos as formas pelas quais diferentes estruturas de igualdade são estruturadas em relação umas às outras, bem como as formas em que as pessoas habitam essas várias vertentes" (MONRO; 
RICHARDSON, 2010, p. 214). Como discutimos anteriormente, vale ressaltar a necessidade de concebermos as distintas hierarquizações entre as categorias de gêneros e sexualidades: No espectro social, a heteronormatividade e a heterossexualidade são duplamente superiores a todas as demais categorizações. Em relação às identidades de gênero LGBTQIA+ e às homossexualidades, a relação é de superioridade, autoridade e subjugação dos primeiros que se colocam como a norma, a verdade e o natural. Ao insistentemente proclamar que Matheusa é Matheus (isso é reiterado na manchete e no início da notícia, ou seja, nas três primeiras informações da notícia de Pennaforte), fica claro que a categoria heteronormativa se sobressai em relação à não heteronormativa; silencia-se e se apaga, desse modo, Matheusa.

3. Por fim, a interseccionalidade "anticategórica" colabora com os entendimentos, por exemplo, de uma "política LGBT assimilacionista que se baseia em homens e mulheres 'discretos' e categorias de casais monogâmicos do mesmo sexo/sexo oposto que se opõe à visibilidade queer" (MONRO; RICHARDSON, 2010, p. 214). Deveras, cabe questionar o quanto essas recusas de vivências em relação às (homos) sexualidades e gêneros, por parte dos que se consideram "discretos" (mas que efetivamente transitam nos espectros das sexualidades), escancaram o que Foucault chamou de hipótese repressiva (FOUCAULT, 1988, p. 21): "sem mesmo ter que dizê-lo, o pudor moderno obteria que não se falasse dele [o sexo], exclusivamente por intermédio de proibições que se completam mutuamente: mutismos que, de tanto calar-se, impõe o silêncio. Censura". Matheusa, mesmo tendo sua identidade de gênero silenciada e apagada na notícia em questão, nos convida a desafiar a censura imposta pela sociedade moderna; censura imposta àqueles que "saíram do armário" e somente desejam vivenciar as suas identidades e sexualidades, mas também àqueles que, por meio de silenciamentos e recusas, não são capazes de vivenciá-las abertamente.

$\mathrm{Na}$ esteira do necessário trabalho autocrítico, não se intenta aqui superdimensionar a interseccionalidade e suas categorias, afirmando que somente elas dariam conta da complexidade dos estudos de gêneros e das (homos)sexualidades. Os estudos interseccionais sofreram duras críticas, haja vista certo desejo de estabelecer diálogos entre categorias fixas de identidades. A esse respeito, Puar critica que 
de fato, muitas das estimadas categorias do mantra interseccional, originalmente entrelaçadas com raça, classe, gênero e, incluindo agora sexualidade, nação, religião, idade e deficiência, são o produto de agendas e regimes coloniais modernistas de violência epistêmica, operando através de uma formação epistemológica ocidental/euro-americana através da qual emergiu toda a noção de identidade. (PUAR, 2012, p. 54)

Na mesma direção, Cooper (2015, p. 8) sustenta que "a interseccionalidade depende da produção e reprodução de categorias de identidade fixas que estão ligadas aos aparatos do estado-nação, que é em si mesma uma categoria problemática”. Em um de seus trabalhos precursores, Puar (2007, p. 212) argumenta a favor de outras perspectivas em relação às identidades, que não perpassariam necessariamente os estudos interseccionais: "ao contrário de um modelo interseccional de identidade, que presume que componentes de raça, classe, gênero, sexualidade, nação, idade, religião podem ser analisados separadamente, e 'desmontados", Puar defende "um agenciamento" que estaria mais sintonizado com o entrelaçamento de forças (identidades) que "se fundem e se dissipam no tempo, espaço e corpo contra a linearidade, coerência e permanência" (PUAR, 2007, p. 212).

Partindo dos conceitos de outras possibilidades de formações identitárias, Puar (2007, p. 211) propõe a noção de queer assemblages (assemblagens queer), com base em Deleuze e Guattari (2001). Assim é que assemblages são, tal como o conceito de rizoma de Deleuze e Guattari, dispersões que estão mutuamente implicadas e conectadas por meio de redes babélicas.

Desse modo, Puar sugere que, ao invés de olharmos para as identidades e, por conseguinte, as sexualidades, como categorias separadas e, de certa forma, mesmo que em constante diálogo, estáveis, visionemos modos 'pósidentitários' que sejam capazes de desestabilizar quaisquer categorizações e separações, focalizando não mais nos atores e suas identidades, mas nos modes of being and doing, quais sejam, nas interseções do ser e do "sendo", ou como diria Derrida (2002), nos jogos de linguagem que desestruturam e descontroem quaisquer binarismos e categorizações fixas.

Corroborando Taylor, Hines e Casey, avaliza-se que "uma estrutura binária persiste na teorização do gênero e da sexualidade", pois enquanto alguns teóricos entreveem "a sexualidade como a categoria pela qual o gênero é construído", outros "posicionam o gênero como a categoria central 
através da qual as identidades e subjetividades sexuais são produzidas" (TAYLOR; HINES; CASEY, 2010, p. 3).

Esses estudos vão ao encontro dos questionamentos de Butler (2003, p. 45), para quem "a instituição de uma heterossexualidade compulsória e naturalizada exige e regula o gênero como uma relação binária em que o termo masculino é diferenciado de um termo feminino, e essa diferenciação é realizada através das práticas do desejo heterossexual".

Portanto, diante do exposto, a segunda morte de Matheusa, simbolicamente assassinada mais uma vez por meio do apagamento e silenciamento de suas identidades de gênero e sexualidades, em nome da heteronormatividade/heterossexualidade imbuída propositalmente na publicação de sua morte pelo jornal O Estado de São Paulo, ratifica a importância de não somente nos posicionarmos academicamente (e humanamente) em relação a essa manipulação jornalística, mas também reforçarmos via estudos intersecionais e rizomáticos, a potência dessas investigações para visões menos fixas e dicotômicas em relação às diversidades humanas.

\section{Raça, racismo e interseccionalidade: a terceira morte de Matheusa}

Segundo as problematizações de Wodak e Reisigl (2001), linguisticamente, o termo raça possui etimologia relativamente recente em termos de história humana, tendo se originado, provavelmente, das famílias de línguas latinas italiana ( $r a z q a)$, espanhola ( $r a z a)$, portuguesa ( raça) e francesa (race) a partir do século XIII, com ocorrências mais frequentes a partir do século XVI, quando o termo aparece em língua inglesa (race). Foi somente a partir das teorias sociodarwinianas do século XIX que aparentemente o termo se conectou às ideias de estado-nação e de modernidade, tornando-se termo chave para as ciências naturais.

Ainda segundo as referidas autoras, "do ponto de vista funcional, raça é uma construção social” (WODAK, REISIGL, 2001, p. 373), embora venha sendo utilizada como uma ferramenta ideológica com função de "oprimir e explorar grupos sociais específicos ao mesmo tempo em que os nega recursos materiais, culturais e políticos". De outros modos e paralelamente, esses mesmos grupos têm se apropriado do termo para construir identidades positivamente alternativas e autoidentitárias que servem como base para políticas de resistência, autonomia, independência 
e participação (WODAK, REISIGL, 2001, p. 373). A esse respeito, LadsonBillings (2009) complementa que tais posicionamentos políticos estão no bojo dos estudos críticos sobre raça (critical race theory) que emergiram nos Estados Unidos na metade da década 1980, após descontentamentos com as leis que prosseguiam corroborando desigualdades sociais e hierarquizações no tocante às raças. Seus pressupostos sustentam que: 1. o racismo é algo rotineiro, não é uma aberração na sociedade estadunidense; 2. contar histórias e narrativas negras é uma forma importante para explorar a raça e o racismo na sociedade; 3. os teóricos dos ECR criticam o liberalismo (LADSON; BILLINGS, 2009). Embora iniciados nos Estados Unidos, percebe-se uma ligação intrínseca com a sociedade brasileira por conta dos mesmos desafios e visões sobre raça. Outrossim, vale enfatizar que para esta reflexão focaliza-se somente a raça negra, por meio do exemplo de Matheusa e que, tem-se consciência de um espectro extenso de raças não brancas, não hegemônicas, não "europeias" e, por isso, pormenorizadas em nosso país.

Em relação ao racismo, Wodak e Reisigl (2001) criticam o fato de a palavra estar massivamente presente nas literaturas (por exemplo, hoje em dia fala-se de racismo cultural, etnopluralista, institucional, velho, novo e neorracismo, bem como racismo de elite, racismo positivo, entre outros), porém, ressaltam que essa presença não significa necessariamente que o racismo esteja sendo problematizado politicamente ou que se tenha avançado em práticas sociais antirracistas.

O termo racismo veio à tona na década de 1930 quando, consoante Fredrickson (2002, p. 5), "uma nova palavra foi necessária para descrever as teorias sobre as quais os nazistas basearam sua perseguição aos Judeus". Superficialmente, trata-se de um conjunto de crenças e atitudes em relação àqueles que possuem uma raça diferente. Contudo, para os estudos de Fredrickson (2002, p. 6), “O racismo, portanto, é mais do que teorizar sobre as diferenças humanas ou pensar mal de um grupo sobre o qual não se tem controle", qual seja,

minha teoria ou concepção de racismo, portanto, tem dois componentes: diferença e poder. Origina-se de uma mentalidade que considera "eles" diferentes de "nós" de maneiras que são permanentes e intransponíveis. Essa sensação de diferença fornece um motivo ou justificativa para usar nossa vantagem de poder para tratar o Outro etnorracial de maneiras que nós consideramos cruel ou injusta se aplicadas a membros do nosso próprio grupo. As possíveis consequências desse nexo de atitude e ação 
variam de discriminação social não oficial ao genocídio, com segregação sancionada pelo governo, subjugação, colonização, exclusão, deportação forçada (ou "limpeza étnica") e escravização. (FREDRICKSON, 2002, p. 9)

Segundo van Dijk (2001, p. 361), "muitos estudos sobre desigualdade étnica e racial revelam uma similaridade impressionante em relação aos estereótipos, preconceitos e outras formas de derrogação verbal presentes nos discursos e na mídia”. De fato, em Matheusa, depreende-se que as questões de raça (e racismo), além de novamente apagadas e silenciadas (tal como foi feito em relação às suas identidades de gênero), são vinculadas aos estereótipos, preconceitos e derrogação verbal. Nesse sentido, “o corpo negro nunca foi concebido como capaz de linearidade e coerência, e certamente de não permanência, particularmente quando se trata de saberes institucionalizados e oficiais (COOPER, 2015, p. 7). Ratificando as contundentes palavras da escritora Mary Church Terell (apud COOPER, 2015 , p. 3), "uma mulher branca tem apenas uma desvantagem a superar a do sexo". Segundo Terell, a mulher negra tem duas, a do sexo e da raça. Esse parece ser o caso de Matheusa, duplamente desafiador por ser homem/ mulher/trans não binária, negra, e de classe considerada desprivilegiada. Embora a foto publicada no Estadão (cf. notícia) mostre claramente sua raça, não há sequer uma menção no texto. Declara-se, assim, sua terceira morte! qual seja, a de sua negritude.

Segundo Yekani, Michaelis e Dietze (2010, p. 81), há um movimento crescente de publicações sobre a teorização crítica queer negra (queer of color critique) ou estudos queer negros (black queer studies) em que um maior engajamento sobre as questões da racialização entrecruzadas com os estudos queer é enfatizado. Esses textos "não são, de maneira alguma, um simples apelo à inclusão; eles apontam para uma crítica epistemológica essencial que desestabiliza o foco no binarismo hétero/homo ou hétero/queer". Essa é a proposta de Ferguson (2004) que cunhou o termo queer of color critique na obra Aberrations in black: toward a queer of color critique. Seu projeto estabelece

a interseccionalidade como uma abordagem explicitamente não identitária dentro do campo conflituoso das políticas de identidade. Consequentemente, não se trata de entender as formações de identidade como entidades estáveis, mas de compreender as relações entrelaçadas entre negritude e estranheza: presume que a ideologia liberal oculta a saliência de interseção entre raça, gênero, sexualidade e classe na 
formação de práticas sociais. (FERGUSON, 2004 apud YEKANI; MICHAELIS; DIETZE, 2010, p. 81)

Semelhantemente Yekani, Michaelis e Dietze (2010) reforçam que tratar de modo simples ou mesmo separadamente as identidades de raça e gênero queer tem se mostrado insatisfatório, dado que "não se trata de uma reavaliação das identidades marginalizadas, mas muito mais de uma rejeição da identificação com essas atribuições categóricas que se tornam hegemonicamente atribuídas”. Na mesma direção, Wodak e Reisigl (2001) questionam de que forma os estudos sobre racismo (termo complexo e multifacetado), responderão às questões: "o que significa ser racista? Quais são as formas de racismo institucional e cultural que enfrentamos hoje em dia, e quais são as suas causas? Como essas formas de racismo se manifestam nos discursos?” (WODAK, REISIGL, 2001, p. 389).

Van Dijk (2001, p. 362), apoiado na obra The End of Racism de D'Souza (1995), afirma que a ACD (análise crítica do discurso) pode colaborar com os estudos interseccionais sobre raça, poder, mídia e, aqui acrescentamos, gêneros e (homos)sexualidades no sentido de desvelar "os tipos de estruturas, estratégias e movimentos discursivos que são implantados no exercício do poder do grupo dominante (branco, ocidental, masculino)", revelando, ainda "como os leitores são manipulados para formar ou confirmar as representações sociais que são adjacentes a uma ideologia conservadora e supremacista".

\section{As mortes de Matheusa no discurso da notícia do jornal Estadão}

Este artigo, além dos conceitos apresentados nas seções anteriores, buscou apoio teórico-analítico nos pressupostos de van Dijk (1998, 2010, 2012, 2016, 2017a, 2017b) para abordar a relação entre discurso, sociedade e cognição. Embora não respondam totalmente às questões supracitadas, nosso desafio é demonstrar que os estudos da ACD, aqui ensejados principalmente pela abordagem sociocognitiva de van Dijk, podem dar as mãos aos estudos da interseccionalidade adicionando às análises sociológicas análises sociocognitivas (ou seja, o entrelaçamento linguístico-dicursivo, cognitivo e social) aprofundadas. No discurso da notícia jornalística "Estudante da Uerj desaparecido foi executado, diz polícia", publicada no jornal Estadão em 6 de maio de 2018, a ideologia se materializa, seja diretamente da "tecelã" da notícia ou oriunda do posicionamento discursivo 
institucional do jornal no qual a notícia foi vinculada e veiculada. Isso porque, para o pesquisador, ideologias, como o racismo, não são inatas, mas aprendidas, e colaboram para a manutenção dos grupos sociais e seus poderes (VAN DIJK, 2017a).

De fato, van Dijk (1998) percebeu, ainda no início dos anos 1990, a necessidade de uma nova dimensão dos estudos relativos às formas de abuso de poder e de dominação intergrupal, a ACD. Em sua ASCD van Dijk defende uma interface entre três conceitos indissociáveis: discurso, cognição e sociedade. Com relação ao discurso, as conclusões do autor ocorrem em diversos momentos, que se complementam e transferem a importância desse conceito às pesquisas textual-discursivas. Van Dijk (1992) relata que desde os anos 1970 surgiu um interesse pelos estudos da memória semântica, que daria margem para a compreensão cognitiva do discurso. Portanto, para o autor a cognição e os modelos mentais estão intrinsicamente relacionados à semântica do discurso, visto que os níveis mais superficiais do discurso, por exemplo, a fonologia, a sintaxe e as grafias são diretamente influenciadas pelas ideologias. No caso Matheusa e das notícias que levam seu nome social ou de registro como referente dessas ideologias "materializadas", a escolha lexical definirá o papel sociopolítico do jornal que transmite e faz repercutir sua morte.

Com relação aos modelos mentais, van Dijk (2017b) atesta que esses são resgatados das experiências dos atores sociais e a partir deles haverá a compreensão dos relatos jornalísticos. Isso quer dizer que as escolhas tendenciosas do jornalista ativarão os modelos mentais como manutenção de poder dominante dos grupos majoritários. Van Dijk (2017b) chama essas escolhas jornalísticas de "modelos preferenciais". Em se tratando do viés ideológico do Estadão, os modelos ativados servirão para mais uma morte de Matheusa, a morte simbólica, oriunda de uma violência, também simbólica, (BOURDIEU, 2014), marcada pelos mecanismos de controle ideológico.

As ideologias mantêm a dominação social por meio do poder exercido sobre as mentes e corpos, como ocorre na ideologia racista, assim como em qualquer outra ideologia segregacionista ou separatista, como a homofobia, o sexismo etc.

As noções de poder e controle, no caso específico de controle mental intergrupal por meio do poder social, atrelam-se quase de forma sinônima na $\mathrm{ACD}$, por serem indissociáveis no mecanismo do discurso. Dentre as formas de dominação, sejam elas beneficiadas pelo poder aquisitivo, por uma 
cultura considerada de maior valor, pela coerção etc., a hegemonia é uma síntese de várias formas de poder social que afeta atores sociais de grupos não hegemônicos, em diversas circunstâncias, sob mais de uma forma de desvalorização do outro. Ou seja, interseccionalmente o dominado é posto em um conjunto de "valores" culturais que na prática segregam ainda mais os indivíduos pertencentes a mais de um grupo minoritário, que coloca em evidência uma vítima social representada pela raça negra, pelos gays, pobres, não binários, mulheres, entre outros.

Interessante observarmos que não necessariamente o dominado de um grupo precisa estar inserido nos demais grupos subjugados socialmente. Dessa forma, pode haver um gay rico que menospreza um grupo de pobres ou mesmo um negro homofóbico. Esses permeiam entre diversos grupos mais marcados na sociedade, sem, contudo, pertencerem unicamente a um polo da relação dominantes versus dominados. Todavia, para pensarmos na condição interseccional, encontramos aqui um exemplo de ator social inserido em diversos grupos minoritários, como a Matheusa, que estava inserida entre os LGBTs, os negros, os pobres e também dentro do universo feminino por causa de sua identidade, ou melhor, em razão da falta de gênero bem determinado. O caso Matheusa é, portanto, um exemplo de vítima de preconceito por vários vieses. Como apontam coletivos de políticas afirmativas, Matheusa é uma "bicha preta". ${ }^{3}$

Segundo van Dijk (2017a), o controle se dá pela aceitação das crenças, além dos conhecimentos do dominador e suas opiniões. Dessa forma, entendemos como o grupo formado pela mídia insere suas ideologias no discurso e reforça os modelos mentais que conceituam como inferiores os componentes dos grupos minoritários. A fim de persuadir o discurso jornalístico, enquanto representante da hegemonia, aproveita-se de elementos linguísticos julgadores e delimitadores para manter o poder hegemônico, assim como utiliza a estratégia do silenciamento e da negação para desqualificar e tentar apagar a existência dos grupos minoritários.

Ao apontarmos a inclinação político-ideológica do jornal $O$ Estado de S. Paulo como conservadora e neoliberal, tendo em vista sua ligação direta

\footnotetext{
${ }^{3}$ O termo "bicha preta" é estudado por membros de coletivos de políticas afirmativas, como o Afrobapho. Seu idealizador, Alan Costa, em artigo de opinião no Correio Nagô menciona o papel das pessoas classificadas como "bichas pretas", no qual exemplifica a condição de ora objeto, ora abjeto e por poucas vezes tratadas com afeto.
} 
com o empresariado paulista, seja por meio da sua condição mercadológica dentro de um regime capitalista, seja por atender linguístico-discursivamente uma elite econômica, compreendemos o papel desse jornal no processo de dominação mental como um dos representantes do grupo social hegemônico que polariza não somente um dos grupos sociais nos quais Matheusa estava inserida, mas todos os outros grupos que representam o lado oposto ao institucionalizado pelo Estadão, isto é, os grupos sociais menos favorecidos, como pobres, negros, LGBTs, e as mulheres, que mesmo inseridas em grupos de poder, ainda são minorias sociais em uma sociedade conduzida pelo modelo patriarcal. Todos esses grupos são desfavorecidos em relação à representatividade social nas produções discursivas dos grandes jornais brasileiros, como o Estadão.

Em Guilherme (2018) um apanhado histórico e político do jornal $O$ Estado de S. Paulo reforça nossas pesquisas sobre a polarização discursiva do grupo compreendido pela representatividade do Estadão em relação aos grupos minoritários, nos quais Matheusa estava inserida. Sobre o posicionamento do jornal, o pesquisador aponta que, desde o editorial, o direcionamento ideológico de seus proprietários é delimitado, influenciando diretamente a construção discursiva dos demais jornalistas da empresa, que no campo simbólico contribuirão para a "construção da opinião pública". Por mais que o jornal tenha a liberdade de expressão como objeto democrático de comunicação com seu leitor e premissa de responsabilidade social, a empresa jornalística, de forma contraditória, selecionará o grupo que terá direito a essa liberdade tanto de escrever quanto de consumir os textos jornalísticos, ou seja, a elite simbólica e hegemônica e de forma excludente, simbolicamente, os grupos minoritários.

Do mesmo modo que se atenta para os destaques de capa ou topo de página das matérias e opiniões publicadas, é preciso atentar para o que não é publicado ou o é sem destaque. No caso dos jornais, o público leitor é mais elitizado: são os chamados formadores de opinião que, a partir da leitura do periódico, atuarão socialmente na propagação da narrativa por eles consumida diariamente (GUILHERME, 2018, p. 203):

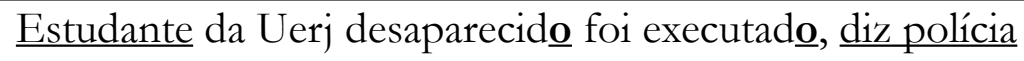
(grifos e negritos dos autores) 
Como estratégia linguística de negação de gênero ou apagamento, o jornal O Estado de S. Paulo utiliza no título da notícia termos generalizantes, com qualificadores no masculino e voz passiva sem agente, acompanhado de um verbo dicendi que assume um duplo efeito já que está no lugar do agente da passiva e corresponde a uma fala de uma autoridade, responsável pelo seu dizer e pelo dito. Assim, o título da notícia não só apaga o lugar do criminoso, mas também se distancia do valor de verdade da proposição e referência a vítima com um substantivo comum de dois gêneros, reforçando o poder simbólico e o machismo na e da própria língua, que tende a marcar o gênero no masculino.

Essa escolha linguística e discursiva não nos parece desprovida de valor ideológico sobre o grupo trans, como comprova a continuação da notícia em seu lead, "Matheus Passarelli Simões Vieira, de 21 anos, foi assassinado em uma favela da zona norte do Rio; corpo da vítima teria sido queimado por traficantes", no qual o nível de informação é maior. Nota-se que o uso do nome próprio marca o posicionamento do jornal que poderia usar o nome social da vítima, mas faz questão de apresentá-la conforme sua certidão de nascimento, no masculino, indicando a idade do transexual e o lugar onde ele foi assassinado. Novamente, no primeiro período do lead, o leitor tem a informação reforçada de que se trata de homicídio, com a indicação do nome completo da vítima, de sua idade e do lugar, apagando, novamente, nessa estrutura de voz passiva o responsável pelo crime.

No período seguinte, o uso da voz passiva prototípica não parece ter o mesmo efeito argumentativo, já que não se trata mais de um nome próprio (no masculino ou no feminino), mas de um corpo ou da ausência dele, reforçando a falta de materialidade do crime pelo fato de esse corpo "ter sido queimado”. Seguindo a mesma estrutura de apagamento, o responsável pela ação é nominado de forma genérica "por traficantes". O lead, então, reforça o posicionamento patriarcal da instituição jornalística que, sabendo que muitos leitores de jornais leem apenas o título e o lead, deixa de transmitir uma informação importante: que se trata do assassinato de uma ativista, no intervalo de dois meses da morte de Marielle Franco, também negra e mulher, perdendo a oportunidade de atuar com seriedade sobre um crime de homofobia e de extermínio do povo negro, pobre, à margem da sociedade, periférico, não binário e apela para a apresentação de apenas mais um caso de violência, entre tantos outros, que ocorre no Rio de Janeiro, sem considerar as opressões interseccionais sofridas por atores sociais que percorrem mais 
de um grupo não hegemônico, portanto, passíveis de violências instituídas por várias ideologias repressoras.

Ao longo da notícia, encontramos diferentes formas de referenciação para Matheusa, escolhas estratégicas para a construção discursiva de um projeto de querer dizer que cria uma cadeia referencial. O primeiro referente introduzido na notícia é "estudante" que recebe ao longo do texto noticioso diferentes denominações, Matheus, o rapaz, o universitário. Essas escolhas não são aleatórias, pois constituem-se como recurso eficiente de orientação para o leitor sobre qual ponto de vista está sendo assumido pelo jornal.

A notícia também investe no discurso relatado, quer seja no discurso de outrem em citação direta, quer indireta ("diz polícia", "Segundo Gabriel”, "A Delegacia de Descoberta de Paradeiros, que investiga o caso", "a polícia não informou", "divulgou a polícia", "A Pró-Reitoria de Políticas Estudantis da UFRJ havia manifestado", "O irmão escreveu", "segundo informações colhidas pela DDPA", “diz o texto” etc.) demonstrando o distanciamento do jornal com a questão minoritária, pois não houve, nesse caso específico, investigação jornalística, mas uma sequência de relatos acrescidos da ideologia do grupo pertencente ao jornal O Estado de S. Paulo.

O conteúdo noticioso relata o acontecimento construindo uma imagem marginalizada de Matheusa e reforça modelos mentais estereotipados sobre o crime, ou seja, ao dizer que Matheus(a) "teria sido queimado por traficantes", "foi executado", "havia saído sozinho de uma festa" "não deu mais notícias", "foi assassinado numa favela", "ao sair de uma festa no Morro do 18”, o discurso construído pela notícia corrobora a marginalização desse ator social, por naturalizar o crime associado à condição interseccionalizada da vítima pelo gênero, raça, classe social, local, e escolaridade.

Matheusa é estudante de uma universidade pública, frequenta um curso transgressor, é gay, é negro/a, é pobre, condições que justificariam para o leitor prévio, tão hegemônico quanto a instituição jornalística, sua execução tão violenta dentro de uma favela no Rio de Janeiro. Melo (2012) assevera que as referências utilizadas por meio de figuras compostas por autoridades ou por instituições além de darem credibilidade ao relato, tornam empáticas e naturais as situações relatadas. Dessa forma, percebemos que o meio midiático naturaliza a relação interseccional Matheusa versus homossexualidade versus marginalidade versus drogas versus criminalidade, isto é, a perpetuação da mentalidade marginal relacionada às identidades de 
gênero não convencionalizadas pelo patriarcalismo e pelo conservadorismo. Ao relacionar Matheusa à favela, local onde foi morta, e correlacionar a vítima a supostas transgressões sociais, ainda que lícitas, a notícia relativiza sua morte física.

Além disso, o uso excessivo das escolhas linguísticas como "estudante", "desaparecido", "executado", "o rapaz", "ele”, "aluno", "assassinado" e "universitário" etc., reforça, ora sob a desculpa da própria condição machista da língua portuguesa, ora sob a suposta objetividade e imparcialidade jornalística, a negação não binária de Matheusa, além de reforçar o modelo mental de que a identidade de gênero se dá somente pelo caráter biológico.

A negação da condição feminina de Matheusa é representada a todo momento por escolhas machistas, seja pelo uso do nome de registro, Matheus Passarelli Simões Vieira, e não pelo nome social no feminino, seja por não aprofundar sua condição de componente de grupos minoritários - isto é, por apagar os vieses opressores por meio do discurso direto - mas sim, por menções vagas nas quais são reforçados modelos mentais que corroboram o preconceito social e de gênero, como por exemplo, a informação de que ela estava antes de ser morta em uma festa no Morro do 18 (região humilde da zona norte do Rio, considerada perigosa em termos de segurança), além da sua identificação de gênero, ora feminina, ora masculina. A manipulação por meio do discurso midiático ocorre somente ideologicamente, visto que, para Boldt (2013), a linguagem utilizada nas relações só pode ser considerada discurso quando nela há ideologia impregnada e essa manipulação discursiva penetra na sociedade, alcançando as massas consolidadas por seus valores e constituindo a realidade dessas pessoas. Portanto, por meio das escolhas da mídia o conhecimento público é selecionado sob critérios de relevância e ideologias próprias.

A identidade ou dupla identidade da vítima é outra negação na produção do relato noticioso visto que o jornal atribui somente à Matheusa a responsabilidade de sua autoidentificação também feminina: "Identificava-se tanto com o gênero masculino quanto com o feminino, e era ora chamado de Matheus, ora de Matheusa" e "O universitário se identificava tanto com o gênero masculino quanto com o feminino, e era ora chamado de Matheus, ora de Matheusa".

Nota-se nesses excertos que o jornal atribui a ela e a quem a conhecia a escolha pelo nome Matheus ou Matheusa através de duas estruturas muito parecidas: uma com verbo na terceira pessoa do singular + partícula 
se (identificava-se), e a outra com recategorização do referente de forma genérica e masculina (o universitário), além do uso de operadores discursivos comparativos (tanto... quanto) e alternativos (ora...ora), o que pressupõe não só o distanciamento do jornal, mas também a aceitação da própria identidade por Matheusa e da sociedade em relação a ela.

As escolhas dos atores sociais que têm voz na notícia, seja por meio do discurso direto ou indireto, também deixam clara a dificuldade de aceitação das diferenças na e pela própria sociedade. Referimo-nos ao fato de que para os amigos Matheusa era Matheus, "\#Cadê Matheus Passarelli”; na delegacia ele era Matheus, "a Delegacia de Descoberta de Paradeiros, que investiga o caso, informou que Matheus foi assassinado na própria madrugada do dia 29, ao sair de uma festa no Morro do 18"; na pró-reitoria ele era Matheusa, “a Pró-Reitoria de Políticas Estudantis da UFRJ havia manifestado sua atenção ao caso na semana passada, afirmando, numa nota oficial, que "por sua identidade LGBTQ, população comumente exposta a violências, o desaparecimento de Matheusa, como também é conhecida(o)", inspira-nos reforçada preocupação"; e para o jornal ele era Matheus, "Matheus e Gabriel se mudaram para a capital para estudar".

Todas essas escolhas de quem fala e como fala na notícia nos leva a crer que o posicionamento ideológico do jornal, representativo de uma elite simbólica que renega a identidade de gênero, é proposital e visa o deleite de seus leitores e a manutenção do modelo patriarcal. Vale ressaltar um "trocadilho" malicioso das elites simbólicas quando negam o termo "identidade de gênero" e impõem o termo "ideologia de gênero" como forma de desqualificação da autoidentificação enquanto condição ao atribuir a axiologia ideológica como vetor para escolhas de gênero.

Percebemos, em nossa análise, a importância de considerar a interface entre a cognição, o discurso e a sociedade, pois o conhecimento, a representação, a ideologia e a polarização estão interligadas pelas atitudes dos grupos. Van Dijk (2016) afirma que a cognição pessoal se produz pelas nossas atitudes, opiniões, experiências e conhecimentos específicos, enquanto a cognição social se dá pelas atitudes e ideologias partilhadas por grupos. Enquanto a primeira é pessoal, a segunda é genérica. Isso se justifica quanto ao uso de referentes que dão condições à manutenção de modelos mentais marginalizantes no evento comunicativo, pois eles não estão solitários na sua composição pejorativa, isto é, a construção mental ocorre interseccionalmente e passa pela cognição pessoal e pela cognição 
social. Nesse sentido, a Figura 1 - Diversidade e interseccionalidade, de Lanehart (2009), pode ser adaptada em função da notícia sobre Matheusa:

FIGURA 2 - Cognição pessoal e social interseccional

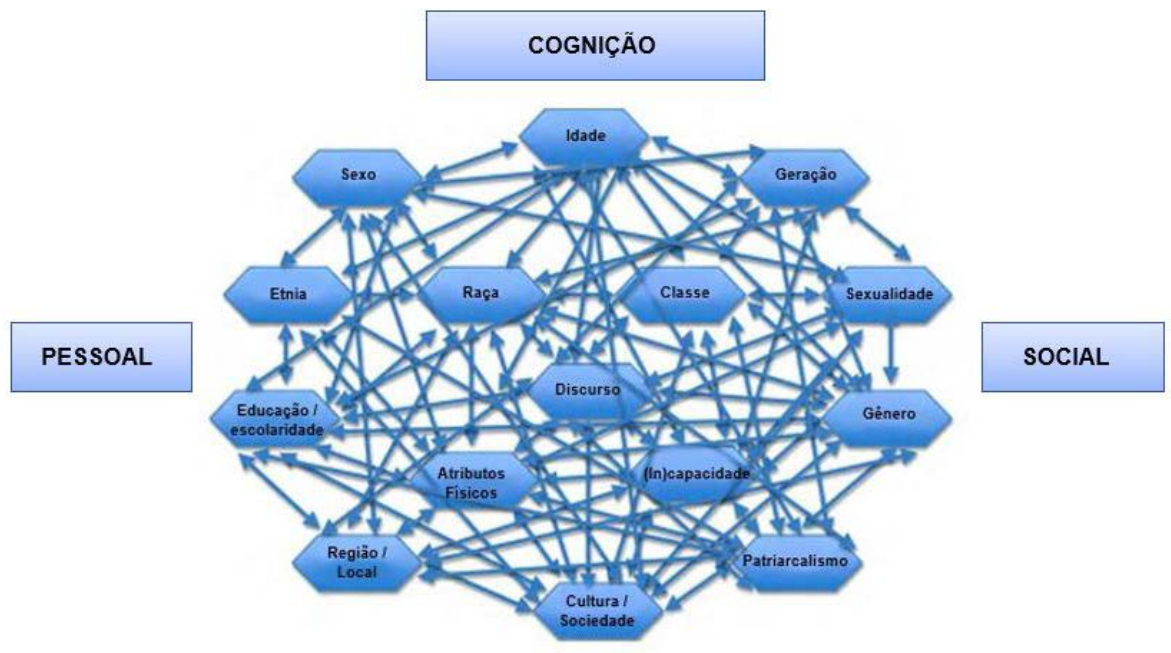

Construímos a Figura 2 com base nas estruturas discursivas, que podem influenciar modelos mentais e manipular crenças, em relação à condição interseccional de Matheusa. Essas estruturas foram encontradas: a) no título e no lead da notícia, que definiram os referentes e os tópicos preferenciais, pelo uso recorrente da voz passiva, ora sem agente, ora analítica plena, referenciando a vítima de forma genérica e apagando quem praticou o crime; b) nas escolhas lexicais, que promovem a negação da identidade de gênero não binário/trans de Matheusa, ao referenciá-la majoritariamente por termos no masculino; c) nas estruturas sintáticas, pelo uso da terceira pessoa do singular + partícula "se", como forma de marcar a responsabilidade da condição identitária da vítima por ela mesma ("identificava-se”); d) pelo uso dos operadores discursivos de comparação ("tanto para o gênero masculino quanto com o feminino"), de alternância ("ora chamado de Matheus, ora de Matheusa"), de adversidade "mas", como contra-argumento que cancela a "veracidade dos fatos" apresentados ("o autor do crime ainda não foi identificado, tampouco a motivação. O corpo foi localizado. Mas a polícia não informou se estava carbonizado"); e) pelo uso de locativos ("em uma favela da zona norte do Rio" - "na região do desaparecimento" - "na escola 
de Artes Visuais do Parque Lage" - "de Rio Bonito, no interior do Rio"); f) pelas pressuposições, ao afirmar obliquamente "fatos" que podem não ser verdade ou relacionados à criminalidade e à violência contra pessoas de grupos minoritários ("teria sido queimado" - "havia saído sozinho" - "foi executado" - "foi assassinado").

A análise do discurso noticioso demonstra que o texto apresenta informações que induzem a construção mental do percurso da vítima desde sua vinda à cidade para estudar, sua despadronização social e de gênero, e a sugestão da sua ida espontânea e natural para o local do crime e ao encontro de seus agentes. Além disso, a notícia afirma ser impossível identificar o autor e a motivação do crime pois o corpo foi encontrado carbonizado.

De toda forma, o uso dos referentes que dão condição marginal ao contexto social em que vivia a vítima naturaliza o desfecho de sua morte. Já a estratégia de polarização discursiva é enfatizada pela notícia que aposta na naturalização e na estereotipação: de um lado da sociedade está o "nós" (a mídia jornalística, seus leitores prévios, as elites simbólicas, os cidadãos de bem, os normais) e, do outro lado, o "eles" (os segregados, os marginalizados, os pobres, os negros, os diferentes, os traficantes, os criminosos), enfim, todos são colocados em um lugar qualquer ou um outro lugar, ou mesmo num lugar menor, todos os que pertencem a outros grupos sociais considerados "inimigos" contra quem a sociedade machista e patriarcal deve lutar com todas as "armas" que estiverem à sua disposição.

\section{Considerações finais}

Ressaltamos a escolha da notícia veiculada pelo Estadão, nesta análise, por entendermos ao contrário de outras (VASCONCELOS, 2018) ${ }^{4}$ que reportaram o mesmo fato, a existência de mais de uma morte de Matheusa, tão cruel quanto a de seu corpo carbonizado, isto é, mortes relacionadas ao apagamento social-linguístico-discursivo de sua plenitude enquanto ser pertencente a um gênero ainda não reconhecido - o não binário - e, interseccionalmente a sua condição de homem/mulher, negro e pobre.

\footnotetext{
${ }^{4}$ Foi lida também a seguinte notícia: “A gente não pode naturalizar o sofrimento', diz irmã de Matheusa Passareli, trans morta no Rio". Disponível em: https://g1.globo.com/rj/ rio-de-janeiro/noticia/a-gente-nao-pode-naturalizar-o-sofrimento-diz-irma-de-matheusapassareli-trans-morta-no-rio.ghtml Acesso em: 28 dez. 2018.
} 
Condições que naturalizam e justificam suas mortes não como importantes dentro da sociedade, mas como consequências das escolhas de não pertencer aos grupos dominantes e majoritários.

Além de enfatizar ações destoantes da ordem social hegemônica, a notícia reforça, como vimos, a vulnerabilidade dos grupos sociais aos quais Matheusa pertence, sua exclusão e sua opressão pela sociedade. Sem dúvidas, o caso Matheusa, assim como outros emblemáticos "escolhidos" como mercadoria pela mídia, carece de maiores estudos que inter-relacionem estudos discursivos, sociológicos e interseccionais (na perspectiva de uma Linguística Aplicada), principalmente nos eixos sociais de gênero social, raça e classe.

Especialmente em relação aos estudos sobre gênero, sexualidade, raça e racismo, quando correlacionados aos estudos interseccionais, concluímos que o apagamento total das identidades de Matheusa, quais sejam, a sua negritude, o fato de ser negra, não binária, gay, trans. Além da morte física, são atestadas as suas mortes simbólicas na notícia publicada pelo jornal em questão. Todas essas questões, somadas ao local onde ocorreu o assassinato, ou seja, a comunidade - um bairro popular de baixa renda do Rio de Janeiro, também nos permite refletir sobre como vêm sendo tratados não só pela mídia, mas também de modo estarrecedor por discursos oficiais governamentais, casos como os de Matheusa Passarelli, Marielle Franco e João Maria Figueiredo: elimina-se a diferente, a negra, a pobre, a trans, a ativista de Direitos Humanos, e tudo bem!

Procuramos, portanto, demonstrar com a análise proposta neste artigo como as "mortes de Matheusa" foram discursivamente construídas pela notícia jornalística a partir de estruturas de apagamento do gênero, raça, autoria do crime, motivação do crime; a partir de estruturas locativas; de estruturas de pressuposições, de escolhas lexicais tendenciosas e das estruturas sintáticas. Vale ressaltar que essas construções discursivas passam pelo viés social e cognitivo, sendo, portanto, construtos que se relacionam interseccionalmente.

Notamos também que a notícia perde uma grande oportunidade de informar sobre questões sociais de extrema importância para a sociedade contemporânea, que são a homofobia, o sexismo, o racismo e o classismo (entre outros), ao escolher intencionalmente reforçar a cultura da naturalização, da banalização, reduzindo a realidade a mero espetáculo da violência. Vê-se na esteira de Debord, que a espetacularização da notícia 
se confunde com a sociedade como uma parte dela e também como seu instrumento. Portanto, a mídia "concentra todo olhar e toda consciência" e por estar à margem da sociedade, torna-se um "lugar do olhar iludido e da falsa consciência", uma "linguagem oficial da separação generalizada" (DEBORD, 1997, p. 14).

\section{Referências}

BOLDT, R. Criminologia midiática: do discurso punitivo à corrosão simbólica do garantismo. Curitiba: Juruá, 2013.

BOURDIEU, P. O poder simbólico. Rio de Janeiro: Bertrand Brasil, 2004.

BUTLER, J. Problemas de gênero: feminismo e subversão da identidade. Tradução de Renato Aguiar. Rio de janeiro: Civilização Brasileira, 2003.

CLARKE, A. Y.; MCCALL, L. Intersectionality and Social Explanation in Social Science Research. Du Bois Review, Cambridge, v. 10, n. 2, p. 349-363, 2013. Doi: https://doi.org/10.1017/S1742058X13000325

COOPER, B. Intersectionality. In: DISCH, L.; HAWKESWORTH, M. The Oxford Handbook of Feminist Theory. Oxford: Oxford University Press, 2015. p. 1-15. Doi: https://doi.org/10.1093/oxfordhb/9780199328581.013.20

COSTA, A. Bichas pretas: entre o objeto, o abjeto - poucas vezes afeto. Correio Nagô, Salvador, 28 jul. 2017. Disponível em: http://bit.ly/36pINay. Acesso em: 23 dez. 2018.

CRENSHAW, K. Demarginalizing the Intersection of Race and Sex: A Black Feminist Critique of Antidiscrimination Doctrine, Feminist Theory and Antiracist Politics. University of Chicago Legal Forum, Chicago, v. 1, n. 1, p. 139-167, 1989. Doi: https://doi.org/10.2307/1229039

CRENSHAW, K. Mapping the Margins: Intersectionality, Identity Politics and Violence Against Women of Color. Stanford Law Review, Stanford, v. 43, p. 1241-1299, 1991. Disponível em: https://heinonline.org/HOL/Page?handle=hein.journals/ stflr43\&id=1257\&collection=journals\&index =. Acesso em: 10 nov. 2019.

DEBORD, G. A sociedade do espetáculo: comentários sobre a sociedade do espetáculo. Trad. Estela dos Santos Abreu. Rio de Janeiro: Contraponto, 1997.

DELEUZE, G.; GUATTARI, F. A Thousand Plateaus: Capitalism and Schizophrenia. London: Athlone Press, 2001.

DERRIDA, J. A escritura e a diferença. 3. ed. São Paulo: Perspectiva, 2002. 
D'SOUZA, D. The End of Racism: Principles for Multiracial Society. New York: Free Press, 1995.

FOUCAULT, M. A história da sexualidade: a vontade de saber. Rio de Janeiro: Graal, 1988. v. 1.

FREDRICKSON, G. M. Racism: A Short History. Princeton: Princeton University Press, 2002.

FREITAS, P. Criminologia midiática e Tribunal do Juri: a influência da mídia e da opinião pública na decisão dos jurados. 2. ed. Niterói: Impetus, 2018.

GUILHERME, C. A. S. A. A imprensa como partido político-ideológico: o caso do jornal O Estado de S. Paulo. Dimensões, Vitória, v. 40, p. 199-223, 2018. Doi: https:// doi.org/10.23871/dimensoes-n40-17905

HALL, S. A identidade cultural na pós-modernidade. 11. ed. Rio de Janeiro: DP\&A, 2006. IZHARUDDIN, A. Intersectionality: The Essay (Part 1). Angry Malay Woman - a Feminist Blog, Kuala Lumpur, 17 jan. 2010. Disponível em: http://bit.ly/2oCi3CJ. Acesso em: 19 dez. 2018.

KNUDSEN, S. Intersectionality: a theoretical inspiration in the analysis of minority cultures and identities in textbooks. In: BRUILLARD, E. et al. (ed.). Canght in the Web or Lost in the Textbook? Caen: IARTEM, 2006. p. 61-76.

KWAN, P. Complicity and Complexity: Cosynthesis and Praxis. DePaul Law Review, Chicago, v. 49, p. 673-692, 2000.

LADSON-BILLINGS, G. 'Who You Callin' Nappy-Headed?': A Critical Race Theory Look at the Construction of Black Women. Race Ethnicity and Education, Abingdon, v. 12, n. 1, p. 87-99, 2009. Doi: https://doi. org $/ 10.1080 / 13613320802651012$

LANEHART, S. L. Diversity and Intersectionality. In: ANNUAL SYMPOSIUM ABOUT LANGUAGE AND SOCIETY, 17., 2009, Austin. Proceedings [...]. Austin: University of Texas, 2009. p. 1-7.

LOURO, G. L. Corpo, escola e identidade. Educação \& Realidade, Porto Alegre, v. 25 , n. 2 , p. $56-76,2000$.

LOURO, G. L. Gênero e sexualidade: pedagogias contemporâneas. Pro-Posições, Campinas, v. 19, n. 2, p. 17-23, 2008. Doi: https://doi.org/10.1590/S010373072008000200003

MCCALL, L. The Complexity of Intersectionality. Signs: Journal of Women in Culture and Society, Chicago, n. 30, p. 1771-1800, 2005. Doi: https://doi. org $/ 10.1086 / 426800$ 
MELO. I. F. Introdução aos estudos críticos do discurso: teoria e prática. Campinas: Pontes Editores, 2012.

MONRO, S.; RICHARDSON, D. Intersectionality and Sexuality: The Case of Sexuality and Transgender Equalities Work in UK Local Government. In: TAYLOR, Y.; HINES, S.; CASEY, M. (ed.). Theorizing intersectionality and sexuality: genders and sexualities in the social sciences. London: Palgrave Macmillan, 2010. p. 99-118. Doi: https://doi.org/10.1057/9780230304093_6

PENNAFORTE, R. Estudante da Uerj desaparecido foi executado, diz polícia. $O$ Estado de São Paulo, São Paulo, 6 maio 2018. Disponível em: http://bit.ly/2N6EJEJ. Acesso em: 19 dez. 2018.

PUAR, J. I'd Rather Be a Cyborg Than a Goddess: Becoming Intersectional in Assemblage Theory. Philosophia, London, v. 2, n. 1, p. 49-66, 2012.

PUAR, J. Terrorist Assemblages: Homonationalism in Queer Times. London: Duke University Press, 2007. Doi: https://doi.org/10.1215/9780822390442

STAUNAES, D. Where Have All the Subjects Gone? Bringing Together the Concepts of Intersecionality and Subjetification. NORA, London, v. 11, n. 2, p. 101-110, 2003. Doi: https://doi.org/10.1080/08038740310002950

TAYLOR, Y.; HINES, S.; CASEY, M. (org.). Theorizing Intersectionality and Sexuality: Genders and Sexualities in the Social Sciences. London: Palgrave Macmillan, 2010. Doi: https://doi.org/10.1057/9780230304093

URZÊDA-FREITAS, M. T. Educando para transgredir: reflexões sobre o ensino crítico de línguas estrangeiras/inglês. Trabalhos de Linguística Aplicada. Campinas, v. 51, n. 1, p. 77-97, 2012. Doi: https://doi.org/10.1590/S010318132012000100005

VAN DIJK, T. A. Análise crítica do discurso. In: TOMAZI, M. M.; ROCHA, L. H. P.; POMPEU, J. C. (org.). Estudos discursivos em diferentes perspectivas: mídia, sociedade e direito. São Paulo: Terracota, 2016. p. 19-42.

VAN DIJK, T. A. Cognição, discurso e interação. Org. e apresentação de Ingedore V. Koch. São Paulo: Contexto, 1992.

VAN DIJK, T. A. Critical Discourse Analysis. In: SHIFFRIN, D.; TANNEN, D.; HAMILTON, H. E. (org.). The Handbook of Discourse Analysis. Oxford: Blackwell, 2001. p. 352-371.

VAN DIJK, T. A. Discurso e contexto: uma abordagem sociocognitiva. São Paulo: Contexto, 2012. 
VAN DIJK, T. A. Discurso e poder. Tradução de Judith Hoffnagel e Karina Falcone. 2. ed. São Paulo: Contexto, 2017a.

VAN DIJK, T. A. Discurso, notícia e ideologia: estudos na análise crítica do discurso. Tradução de Zara Pinto-Coelho. Ribeirão: Húmus, 2017b.

VAN DIJK. T. A. Ideología: una aproximación multidisciplinaria. Barcelona: Gedisa, 1998.

VASCONCELOS, P. 'Matheusa Passareli é revolução e amor', diz amiga de estudante executada no Rio. Ponte, São Paulo, 8 maio 2018. Disponível em: http:/ / bit.ly/2JN2RKz. Acesso em: 28 dez. 2018.

VIANA, F. Segundo relatório TGEU, Brasil segue no $1^{\circ}$ lugar do ranking de assassinatos de transexuais. ParadaSP - Associação da Parada do Orgulho LGBT de São Paulo, São Paulo, 27 nov. 2018. Disponível em: http://bit.ly/325QwY0. Acesso em: 13 ago. 2019.

WODAK, R.; REISIGL, M. Discourse and Racism. In: SHIFFRIN, D.; TANNEN, D.; HAMILTON, H. E. (ed.). The Handbook of Discourse Analysis. Oxford: Blackwell, 2001. p. 372-397. Doi: https://doi.org/10.1002/9780470753460.ch20

YEKANI, E. B.; MICHAELIS, B.; DIETZE, G. 'Try Again. Fail Again. Fail Better.' Queer Interdependencies as Corrective Methodologies. In: TAYLOR, Y.; HINES, S.; CASEY, M. (ed.). Theorizing Intersectionality and Sexuality: Genders and Sexualities in the Social Sciences. London: Palgrave Macmillan, 2010. p. 78-98. Doi: https:// doi.org/10.1057/9780230304093_5

Data de submissão: 13/01/2019. Data de aprovação: 17/10/2019. 